\title{
IMPLEMENTASI KEBIJAKAN ABSEN ELEKTRONIK (E-ABSENSI BNI INNOVATION) BERPENGARUH TERHADAP KINERJA PEGAWAI PADA DIVISI \\ JAKARTA COLLECTIONMANAGEMENT PADA PT. BANK NEGARA INDONESIA 1946 (PERSERO) Tbk, JAKARTA-BARAT
}

\author{
Irvan Arif Kurniawan, S.Sos.,M.AP. Hilman, SE, M.Si, Indri Lestari \\ Universitas Islam Syekh-Yusuf Tangerang \\ Email : iakurniawan@unis.ac.id hilman@unis.ac.id indrilestariunis@gmail.com
}

\begin{abstract}
This journal entitled Implementation of Electronic Absence Policy (BNI E-Attendance Innovation) Affects Employee Performance in the Jakarta Division of Collection Management at PT. Bank Negara Indonesia 1946 (Persero) Tbk, West Jakarta". The population in this study are employees who work at PT. Bank Negara Indonesia 1946 (persero) Tbk, West Jakarta, which measured 222 people, from which the researcher used 69 people as samples to be tested. The research method used in this research is the associative method, the data technique used is literature study and field study through observation and questionnaires. Furthermore, it is tested by quantitative analysis using a proportional stratified random sampling technique, and data processing using the SPSS (Product and Solution Service) program.
\end{abstract}

Keyword: Implementation, E-Attendance, the performance

\begin{abstract}
ABSTRAK
Jurnal ini berjudul Implementasi Kebijakan Absen Elektronik (E-Absensi BNI Innovation) Berpengaruh Terhadap Kinerja Pegawai Pada Divisi Jakarta Collection Management Pada PT. Bank Negara Indonesia 1946 (persero) Tbk, Jakarta Barat". Populasi pada penelitian ini adalah pegawai yang bekerja pada PT. Bank Negara Indonesia 1946 (persero) Tbk, Jakarta Barat yang berjumlah 222 orang yang selanjutnya dari seluruh populasi tersebut peneliti menggunakan 69 orang sebagai sampel untuk diuji. Metode penelitian yang digunakan dalam penelitian ini adalah metode asosiatif, teknik pengumpulan data yang digunakan adalah studi kepustakaan dan studi lapangan dengan cara observasi dan angket. Selanjutnya diuji secara analisis kuantitatif dengan menggunakan teknik proportionate stratified random sampling, dan dilanjutkan dengan pengolahan data menggunakan program SPSS (Statistical Product and Solution Service).
\end{abstract}

Kata kunci : Implementasi, E-absensi, Kinerja. 


\section{PENDAHULUAN}

Kinerja pegawai adalah suatu dasar dalam meningkatkan kualitas pegawai dalam bidang apapun, terlebih suatu perusahaan yang besar ataupun dalam skala kecil. Hal ini di fokuskan terhadap pegawai pada perusahaan dalam bidang jasa keuangan, perusahaan harus dapat memberdayakan pegawai sebaik mungkin dalam meningkatkan layanan jasa keuangan kepada masyarakat.

Pentingnya kinerja pegawai dalam pencapaian keberhasilan perusahaan jasa perbankan dalam menjalankan kegiatan operasionalnya sesuai dengan visi dan misi bank yang menjadi tujuan pencapaian terbaik, maka setiap pimpinan perusahaan jasa perbankan berusaha untuk meningkatkan kinerja pegawainya, melakukan upaya peningkatan kinerja pegawai tidak hanya dilakukan dengan cara memberikan pelatihan dan pendidikan bagi pegawai sesuai dengan bidangnya masing-masing, tetapi juga kesuksesan perusahaan bisa dilihat dari pekerjaan yang telah dicapai oleh pegawainya.

Kehadiran pegawai di buktikan dengan daftar hadir atau absensi, absen yang di lakukan saat kedatangan pegawai dan saat pegawai selesai pada jam kerja yang telah di tentukan. Bahkan dalam segi kehadiran pun pegawai harus di tuntut mampu memberikan kinerja yang baik melalui suatu sistem aplikasi yang disebut absen elektronik (E-Absensi BNI Innovation). E-absensi BNI Innovation adalah sebuah aplikasi pencatatan absensi untuk internal, menggunakan pin yang diperoleh dari sistem internal dari perusahaan itu sendiri, yang dimana aplikasi tersebut sampai saat ini sudah di terapkan dalam PT. Bank Negara Indonesia 1946 (persero) Tbk. Namun permasalahannya adalah masih banyaknya pegawai yang belum mampu menunjukan kinerja yang baik dan optimal seperti :

1. kurangnya loyalitas kerja untuk datang lebih awal ke kantor karena dalam absensi bisa melakukan cek-in absen di sekitar kantor cabang lain.

2. pegawai sering mengalami gangguan sinyal untuk melakukan cek-in absensi.

3. belum di terapkannya absensi elektronik pegawai secara menyeluruh.

4. $\quad$ sering terjadi hambatan untuk validasi absensi dengan sistem. 


\section{TINJAUAN PUSTAKA}

\section{Implementasi Kebijakan}

\section{a. Pengertian Implementasi Kebijakan}

Menurut Van Metter dan Van Horn dalam Sahya Anggara (2018:232) menyatakan bahwa, “Implementasi Kebijakan adalah tindakan-tindakan yang dilakukan baik oleh individu/pejabat atau kelompok pemerintah atau swasta yang diarahkan pada tercapainya tujuan yang telah digariskan dalam keputusan kebijakan".

\section{b. Faktor-faktor yang mempengaruhi implementasi kebijakan}

Ada banyak teori yang menjelaskan tentang Implementasi Kebijakan, salah satunya menurut Van Metter \& Van Horn dalam Agustino Leo (2017: 133), ada 6 (enam) indikator yang mempengaruhi implementasi kebijakan, antara lain sebagai berikut :
a. Ukuran dan Tujuan Kebijakan
b. Sumber Daya
c. Karakteristik Agen Pelaksana
d. Sikap atau Kecenderungan (Disposition) Para Pelaksana
e. Komunikasi Antar-Organisasi dan Aktivitas Pelaksana
f. Lingkungan Ekonomi, Sosial, dan Politik

\section{Pengertian Absen Elektronik (E-Absensi BNI Innovation)}

\section{a. Pengertian Absen Elektronik}

Absen elektronik yaitu sebuah alat berbasis teknologi yang telah diatur secara otomatis dan telah di masukan seluruh data pegawai didalamnya sehingga secara otomatis dapat menginput kehadiran dan kepulangan pegawai. Absen elektronik terbagi beberapa macam yaitu berupa sidik jari (finger print), melalui wajah (faceprint) dan berbasis aplikasi (E-Absensi).

\section{b. Pengertian E-Absensi BNI Innovation}

E-Absensi BNI Innovation adalah sebuah aplikasi pencatatan absensi untuk internal, menggunakan pin yang diperoleh dari sistem internal dari perusahaan itu sendiri, yang dimana aplikasi tersebut sampai saat ini sudah di terapkan dalam PT. Bank Negara Indonesia 1946 (persero) Tbk, Jakarta Barat. 


\section{Kinerja Pegawai}

\section{a. Pengertian Kinerja Pegawai}

Menurut Swanson dan Holton yang dikutip oleh Keban (2004:99) menyatakan bahwa, "Kinerja Pegawai secara individu dapat dilihat dari apakah misi dan tujuan pegawai sesuai dengan misi lembaga, apakah pegawai menghadapi hambatan dalam bekerja dan mencapai hasil, apakah pegawai mempunyai kemampuan mental, fisik, emosi dalam bekerja, dan apakah mereka memiliki motivasi yang tinggi, pengetahuan, keterampilan dan pengalaman dalam bekerja".

\section{b. Faktor-faktor yang mempengaruhi kinerja pegawai}

Ada banyak penjelasan tentang Kinerja Pegawai, salah satunya menurut Swanson dan Halton yang dikutip oleh Keban (2004:99), ada 9 (sembilan) indikator yaitu :

1. Kualitas Kerja

2. Kuantitas Kerja

3. Kehadiran dan Ketepatan Waktu

4. Kerjasama

5. Kemandirian Kerja

6. Pengetahuan Tentang Kerja

7. Pengetahuan Tentang Kebijakan dan Tujuan Organisasi

8. Inisiatif dan Penyampaian Ide-Ide yang Sehat

9. Kemampuan Supervisi dan Teknik

\section{METODE PENELITIAN}

Metode penelitian pada dasarnya merupakan cara ilmiah untuk mendapatkan data dengan tujuan dan kegunaan tertentu. Data yang diperoleh melalui penelitian ini adalah data empiris (teramati) yang mempunyai kriteria tertentu yaitu valid. Valid menunjukan derajat ketepatan antara data yang sesungguhnya terjadi pada obyek dengan data yang dapat dikumpulkan oleh peneliti. Setiap penelitian mempunyai tujuan dan kegunaan tertentu, secara umum tujuan penelitian ada tiga macam yaitu yang bersifat penemuan, pembuktian dan pengembangan. Penemuan.

Bentuk metode yang dilakukan dalam penelitian ini digunakan dengan cara pendekatan kuantitatif yang artinya penelitian ini bentuk metode asosiatif yang bertujuan untuk mengetahui pengaruh antara dua variabel X (independen) dan variabel Y (dependen) dengan cara analisa statistik. 


\section{Populasi dan Sampel Penelitian \\ a. Populasi}

Populasi menurut Sugiyono (2016:80) menjelaskan bahwa, "Populasi adalah wilayah generalisasi yang terdiri atas objek dan subjek penelitian yang meimiliki karakterisitik dan kualitas tertentu yang ditetapkan oleh peneliti untuk dipelajari dan kemudian di tarik kesimpulannya".

Berdasarkan dari pemahaman tersebut, maka peneliti menggunakan populasi yang berjumlah 222 orang pegawai yang masih aktif bekerja pada PT. Bank Negara Indonesia 1946 (Persero) Tbk.

\section{b. Sampel Penelitian}

Sampel menurut Sugiyono (2016:81) menjelaskan bahwa. "Sampel adalah bagian dari jumlah dan karakteristik yang di milki oleh populasi tersebut". Bila populasi besar, dan peneliti tidak mungkin mempelajari semua yang ada pada populasi, karena keterbatasan dana, tenaga dan waktu, maka peneliti dapat menggunakan sampel yang di ambil dari populasi itu.

Untuk mengetahui hasil penelitian dibutuhkan yang dinamakan dengan teknik sampling. Teknik Sampling merupakan teknik pengambilan sampel yang digunakan didalam penelitian.

Teknik yang akan digunakan dalam penelitian ini adalah menggunakan teknik Proportionate Stratified Random Sampling. Lebih lanjut Sugiyono (2016:82) menjelaskan bahwa, “Teknik sampling Proportionate Stratified Random sampling ialah teknik yang digunakan bila populasi mempunyai anggota/unsur yang tidak homogen atau berstrata secara proporsional".

Karena jumlah pegawai pada PT. Bank Negara Indonesia (persero) Tbk tidak lebih dari 1000 orang (222 orang), maka peneliti menggunakan rumus slovin pada pegawai di PT. Bank Negara Indonesia (persero) Tbk, Jakarta Barat.

Rumus :

$$
n=\frac{\mathrm{N}}{1+\mathrm{Ne}^{2}}
$$

Keterangan :

$$
\mathrm{n}=\text { Ukuran sampel }
$$




$$
\begin{aligned}
& \mathrm{N}=\text { Ukuran Populasi } \\
& \mathrm{e}=\text { Standar Error }(10 \%)
\end{aligned}
$$

Diketahui jumlah populasi sebanyak 222 orang pegawai, maka perhitungan jumlahnya sebagai berikut :

$$
\begin{aligned}
& n=\frac{\mathrm{N}}{1+\mathrm{Ne}^{2}} \\
& n=\frac{222}{1+222(10 \%)^{2}} \\
& n=\frac{222}{1+222(0,1)^{2}} \\
& n=\frac{222}{1+222(0,01)} \\
& n=\frac{222}{1+2,22} \\
& n=\frac{222}{3,22} \\
& n=68,9440 \\
& n=69
\end{aligned}
$$

Jadi jumlah sampel yang digunakan dalam penelitian ini 69 dari 222 populasi.

\section{Operasional Variabel}

Menurut Sugiyono (2010:4) menjelaskan bahwa, “Operasional Variabel adalah segala sesuatu yang dibentuk apa saja yang ditetapkan oleh peneliti untuk dipelajari sehingga diperoleh informasi tentang hal tersebut, kemudian ditarik kesimpulan.

\section{Instrumen Penelitian}

Menurut Arikunto (2013:203) menyatakan bahwa, “Instrumen Penelitian adalah alat atau fasilitas yang digunakan oleh peneliti dalam mengumpilkan data agar pekerjaannya lebih mudah dan hasilnya lebih baik, dalam arti lebih cermat, lengkap, dan sistematis sehingga lebih mudah diolah".

\section{a. Teknik Pengumpulan Data}

Teknik pengumpulan data yang dilakukan peneliti adalah sebagai berikut :

1. Studi kepustakaan (library research) yaitu pengumpulan data dilakukan dengan mempelajari dan menganalisa buku-buku atau bahan-bahan tertulis lainnya yang hubungannya dengan penelitian yang dilakukan.

2. Studi lapangan (field research) yaitu kegiatan pengumpulan data dengan cara melakukan penelitian langsung pada obyek penelitian, dengan teknik pengumpulan data sebagai berikut : 
- Observasi

- Interview (wawancara)

- Dokumentasi

- Kuesioner (angket)

\section{Uji Validitas dan Reliabilitas}

Uji validitas dan reliabilitas perlu dilakukan untuk mengetahui apakah percobaan suatu instrumen (alat ukur) dalam pengambilan data untuk penelitian itu valid atau reliabel. Untuk mengetahui lebih lanjut pengujian ini dapat dilihat pada uraian dibawah ini :

\section{a. Uji Validitas}

Uji validitas yaitu untuk mengukur tiap butir instrumen yang dilakukan dengan menganalisis hubungan skor tiap butir dan skor total dengan menggunakan rumus product moment. Menurut Sugiyono (2016:121) mengemukakan bahwa validitas berarti instrumen tersebut dapat digunakan untuk mengukur apa yang seharusnya diukur.

Jadi, untuk mengetahui validitas atau tidaknya, maka diperlukan pengujian skor totalnya. Kuesioner penelitian dikatan valid bila skor tersebut berkorelasi secara signifikan dengan skor totalnya.

- Apabila r hitung > r tabel, maka Ho ditolak. Artinya valid.

- Apabila r hitung < r tabel, maka Ho diterima. Artinya tidak valid.

\section{b. Uji Reliabilitas}

Menurut Priyatno (2017:18) mengatakan bahwa, "Reabilitas adalah suatu ukuran yang menunjukan sejauh mana hasil pengukuran tetap konsisten bila dilakukan dua kali atau lebih terhadap gejala yang sama dan dengan alat pengukuran yang sama".

Uji Reabilitas digunakan untuk mengetahui konsistensi alat ukur, apakah alat ukur yang digunakan dapat diandalkan dan tetap konsisten jika pengukuran tersebut diulang. Dalam penelitian ini, peneliti menggunakan program SPSS 21.0

Keputusan uji :

- Apabila r hitung $>\mathrm{t}$ tabel, maka Ho di tolak. Artinya Reliabel.

- Apabila $r$ hitung $<\mathrm{t}$ tabel, maka Ho diterima. Artinya Tidak Reliabel.

c. Uji Normalitas 
Pengujian normalitas data digunakan untuk menguji apakah data kontinue berdistribusi normal sehingga dengan menggunakan korelasi person product moment persyaratan terpenuhi. Data dikatakan berdistribusi normal bila kurva memiliki kemiringan yang seimbang dari sisi kanan ke sisi kiri.

\section{Teknik Analisis Data dan Pengujian Hipotesis}

Menurut Priyatno (2017:10) mengatakan bahwa, Analisis data adalah proses mengolah data dari penginterprestasikan hasil pengolahan data.

\section{a. Uji Koefisiensi Korelasi}

Analisis ini digunakan untuk menentukan kuat tidaknya atau derajat keeratan hubungan antara variabel X (bebas) dan variabel $Y$ (terikat) dan utuk mengetahui arah hubungan yang terjadi. Ukuran yang digunakan untuk melihat hubungan kuat tidaknya antara variabel $\mathrm{X}$ dengan variabel $\mathrm{Y}$ dinamakan koefisien korelasi, cara perhitungan menggunakan rumus ini :

$$
r_{x y}=\frac{n \cdot \sum x_{1} y_{1-}\left(\sum x_{1}\right)\left(\sum y_{1}\right)}{\left.\sqrt{\left\{n \cdot \sum x_{1}^{2}-\left(\sum x_{1}\right)^{2}\right\}\left\{n \cdot \sum y_{1}^{2}\right.}-\left(\sum y_{1}\right)^{2}\right\}}
$$

Keterangan :

$$
\begin{array}{ll}
r x y & =\text { Koefisiensi korelasi product moment (korelasi antara } \mathrm{x} \text { dan } \mathrm{y}) \\
n & =\text { Jumlah Sampel, Banyaknya Pasangan Skor X Dan } \mathrm{Y} \\
\mathrm{x} & =\text { Skor Dalam Distribusi Variabel X1 Dan X2 } \\
\mathrm{y} & =\text { Skor Dalam Distribusi Variabel } \mathrm{Y} \\
\sum \mathrm{x}^{2} & =\text { Kuadrat Jumlah Skor } \mathrm{X} \\
\sum \mathrm{y}^{2} & =\text { Kuadrat Jumlah Skor } \mathrm{Y}
\end{array}
$$

\section{b. Uji Koefisiensi Determinasi $\left(r^{2}\right)$}

Uji koefisien determinasi, yaitu untuk mengukur seberapa besar variabel bebas dapat menjelaskan variabel terikat. Teknik analisis ini menggunakan koefisien multi korelasi atau koefisien determinasi $\left(\mathrm{r}^{2}\right)$ nila $\mathrm{r}^{2}$ dapat dijelaskan dengan menguunakan rumus berikut ini :

$$
\mathrm{Kd}=\mathrm{r}^{2} \times 100 \%
$$

Keterangan :

$$
\begin{aligned}
& \mathrm{r}^{2}=\text { Koefisiensi korelasi } \\
& \mathrm{Kd}=\text { Koefisiensi Determinasi }
\end{aligned}
$$




\section{c. Uji Regresi Linear}

Analisis regresi dapat digunakan untuk memutuskan apakah naik dan menurunnya nilai dalam variabel dependen melalui menaikkan atau menurunkan nilai variabel independen. Regresi linier sederhana didasarkan pada hubungan fungsional atau kausal satu variabel bebas dengan satu variabel terikat dengan menggunakan rumus sebagai berikut :

$$
\hat{Y}=a+b X
$$

Keterangan :

$\hat{Y}=$ Subyek dalam variabel terikat yang diprediksi

$\mathrm{a}=$ Harga $\mathrm{Y}$ bila $\mathrm{X}=0$ (harga konstan)

$\mathrm{b}=$ Angka arah atau koefisien regresi, yang menunjukkan angka peningkatan ataupun penurunan variabel dependen yang didasarkan pada variabel independen. Bila $b(+)$ maka naik, bila (-) maka terjadi penurunan.

Untuk mencari besarnya nilai a dan b dihitung dengan rumus sebagai berikut :

$$
\begin{aligned}
& \mathrm{a}=\frac{\left(\sum \mathrm{Yi}\right)\left(\sum \mathrm{xi}^{2}\right)-\left(\sum \mathrm{xi}\right)\left(\sum \mathrm{xiYi}\right)}{n \sum \mathrm{xi}^{2}-\left(\sum \mathrm{xi}\right)^{2}} \\
& \mathrm{~b}=\frac{n \sum \mathrm{xiYi}-\left(\sum \mathrm{xi}\right)\left(\sum \mathrm{Yi}\right)}{n \sum \mathrm{xi}^{2}-\left(\sum \mathrm{xi}\right)^{2}}
\end{aligned}
$$

Harga b merupakan fungsi dari koefisien korelasi. Bila koefisien korelasi tinggi, maka harga b juga besar, sebaliknya bila koefisien korelasi negatif maka harga b juga negatif, dan sebaliknya koefisien korelasi positif maka b juga positif.

\section{d. Uji Hipotesis (t hitung)}

Pengujian hipotesis dapat didasarkan dengan dua hal, yaitu tingkat signifikansi atau problem ( $\alpha$ ) dan tingkat kepercayaan atau interval . adapun rumus yang digunakan sebagai berikut :

$$
t_{\text {hitung }}=\frac{r \sqrt{n-2}}{\sqrt{1-r^{2}}}
$$


Keterangan :

$\mathrm{t}=$ Signifikan Hubungan

$\mathrm{n}=$ Sampel

$\mathrm{r}=$ Koefisien Korelasi

Untuk mengetahui apakah uji hipotesis yang dirumuskan dapat diterima atau ditolak, maka dirumuskan sebagai berikut :

- $\quad$ Jika $\mathrm{t}$ hitung > $\mathrm{t}$ tabel, maka Ho ditolak dan Ha diterima.

Artinya ada pengaruh yang signifikan antara Implementasi Kebijakan terhadap Kinerja Pegawai.

- $\quad$ Jika t hitung < $\mathrm{t}$ tabel, maka Ho diterima dan Ha ditolak.

Artinya tidak ada pengaruh yang signifikan antara Implementasi Kebijakan terhadap Kinerja Pegawai.

\section{PEMBAHASAN}

\section{Variabel $X$ (Implementasi Kebijakan)}

\section{a. Ukuran dan Tujuan Kebijakan}

Berdasarkan hasil observasi dari pegawai yang menggunakan aplikasi E-absensi terdapat 28 responden dengan presentase 40,6\% yang memberi tanggapan sangat setuju. Hal ini dikarenakan bahwa penggunaan sistem E-absensi sudah sesuai dengan standar yang telah diterapkan pada PT. Bank Negara Indonesia 1946 (persero) Tbk, Jakarta Barat. Meski saat ini sudah berjalan, aplikasi tersebut diharapkan mampu lebih baik lagi dan dapat membatu pegawai dalam kehadiran.

\section{b. Sumber Daya}

Berdasarkan hasil observasi dari pegawai yang menggunakan aplikasi E-absensi terdapat 37 responden dengan presentase 53,6\% yang memberi tanggapan setuju. Hal ini dikarenakan bahwa sumber daya yang ada pada PT. Bank Negara Indonesia 1946 (persero) Tbk, Jakarta Barat sudah sesuai dengan kebutuhan para pegawai. Sehingga managemen berharap kedepannya mampu meningkatkan kualitas pelayanan terhadap nasabah. 


\section{c. Karakteristik Agen Pelaksana}

Berdasarkan hasil observasi dari pegawai yang menggunakan aplikasi E-absensi terdapat 29 responden dengan presentase $42,0 \%$ yang memberi tanggapan setuju. Hal ini dikarenakan bahwa kebijakan E-absensi sudah sesuai dengan standar aturan yang berlaku pada PT. Bank Negara Indonesia 1946 (persero) Tbk, Jakarta Barat. Diharapkan para pegawai mampu melaksankan pekerjaannya tanpa adanya ke khawatiran tentang kehadiran.

\section{d. Sikap atau Kecenderungan (disposition) Para Pelaksana}

Berdasarkan hasil observasi dari pegawai yang menggunakan aplikasi E-absensi terdapat 30 responden dengan presentase $43,5 \%$ yang memberi tanggapan setuju. Hal ini dikarenakan bahwa penerapan E-absensi dapat diterima oleh seluruh pegawai pada PT. Bank Negara Indonesia 1946 (persero) Tbk, Jakarta Barat. Sehingga hal ini diharapkan dapat membantu pegawai dalam tinggkat kedisiplinan terutama dalam masalah kehadiran.

\section{e. Komunikasi Antar-Organisasi dan Aktivitas Pelaksana}

Berdasarkan hasil observasi dari pegawai yang menggunakan aplikasi E-absensi terdapat 36 responden dengan presentase 52,2\% yang memberi tanggapan setuju. Hal ini dikarenakan bahwa pegawai mendapatkan kemudahan dalam mengkomunikasikan atau menyampaikan keluhan-keluhan dari kesalahan yang ditimbulkan oleh E-absensi. Sehingga hal ini di harapkan dapat mengurangi miss komunikasi antar pegawai.

\section{f. Lingkungan Ekonomi, Sosial dan Politik}

\section{1) Lingkungan Ekonomi}

Berdasarkan hasil observasi dari pegawai yang menggunakan aplikasi E-absensi terdapat 33 responden dengan presentase 47,8\% yang memberi tanggapan setuju. Hal ini dikarenakan bahwa adanya insentif yang memacu semangat dan gairah bekerja para pegawai, jika kehadiran baik dalam aplikasi E-absensi maupun kinerja kerja yang sangat diharapkan mampu dapat mencapai apa yang diharapkan.

\section{2) Lingkungan Sosial}

Berdasarkan hasil observasi dari pegawai yang menggunakan aplikasi E-absensi terdapat 30 responden dengan presentase 43,5\% yang memberi tanggapan setuju. Hal ini dikarenakan bahwa pegawai menyetujui dengan pemberlakuannya pemakaian E-absensi menyeluruh kepada semua pegawai sehingga tidak adanya kecemburuan antar sosial ke semua pegawai. 


\section{3) Lingkungan Politik}

Berdasarkan hasil observasi dari pegawai yang menggunakan aplikasi E-absensi terdapat 34 responden dengan presentase 49,3\% yang memberi tanggapan setuju. Hal ini dikarenakan bahwa pegawai sering diikut sertakan dalam rapat perusahaan untuk menyelesaikan permasalahan dari hambatan E-absensi serta dapat menyampaikan keluhan atau ide ide baru untuk kemajuan perusahaan.

\section{Variabel Y (Kinerja Pegawai)}

\section{a. Kualitas Kerja}

Berdasarkan hasil observasi dari pegawai yang menggunakan aplikasi E-absensi terdapat 39 responden dengan presentase 56,5\% yang memberi tanggapan kurang setuju. Hal ini dikarenakan bahwa adanya kesenjangan status sosial pegawai dengan pegawai lainnya sehingga mengakibatkan menurunnya kualitas performance pegawai dalam melakukan suatu pekerjaan, sehingga berdampak pada kinerja pegawai dalam jangka panjang.

\section{b. Kuantitas Kerja}

Berdasarkan hasil observasi dari pegawai yang menggunakan aplikasi E-absensi terdapat 32 responden dengan presentase 46,4\% yang memberi tanggapan setuju. Hal ini dikarenakan bahwa hasil pekerjaan yang diberikan oleh pegawai sudah sesuai dengan ketentuan pada PT. Bank Negara Indonesia 1946 (persero) Tbk, Jakarta Barat. Hal tersebut di harapkan agar terciptanya kenyaman dalam memberikan layanan serta pencapaian terbaik pegawai.

\section{c. Kehadiran dan Ketepatan Waktu}

Berdasarkan hasil observasi dari pegawai yang menggunakan aplikasi E-absensi terdapat 31 responden dengan presentase 44,9\% yang memberi tanggapan kurang setuju. Hal ini dikarenakan bahwa pegawai mengeluh akan terjadinya gangguan pada jaringan aplikasi E-absensi, sehingga membuat pegawai terlambat untuk melakukan absen. Serta kekhawatiran pegawai dapat mempengaruhi kinerja pegawai.

\section{d. Kerja Sama}

Berdasarkan hasil observasi dari pegawai yang menggunakan aplikasi E-absensi terdapat 39 responden dengan presentase 56,5\% yang memberi tanggapan kurang setuju. Hal ini dikarenakan bahwa para pegawai bekerja dengan komposisi pekerjaan yang berbeda, sehingga harus adanya saling keterbukaan dan saling perduli satu sama lain agar terciptanya kerja sama sesama pegawai. 


\section{e. Kemandirian Kerja}

Berdasarkan hasil observasi dari pegawai yang menggunakan aplikasi E-absensi terdapat 31 responden dengan presentase 44,9\% yang memberi tanggapan setuju. Hal ini dikarenakan bahwa pegawai dapat bekerja secara mandiri maupun secara tim dalam menyelesaikan pekerjaannya. Dengan demikian haruslah masing-masing pegawai dibekali pengetahuan yang cukup dengan pelatihan sesuai dengan komposisi bidang.

\section{f. Pengetahuan Tentang Kebijakan dan Tujuan Organisasi}

Berdasarkan hasil observasi dari pegawai yang menggunakan aplikasi E-absensi terdapat 32 responden dengan presentase 46,4\% yang memberi tanggapan setuju. Hal ini dikarenakan bahwa pegawai sudah mengetahui kebijakan dan tujuan organisasi dari PT. Bank Negara Indonesia 1946 (persero) Tbk, Jakarta Barat. Tetapi sosialisasi haruslah diberikan dengan sesuai harapan dan target yang ingin di capai.

\section{g. Inisiatif dan Penyampaian ide-ide yang Sehat}

Berdasarkan hasil observasi dari pegawai yang menggunakan aplikasi E-absensi terdapat 30 responden dengan presentase $43,5 \%$ yang memberi tanggapan kurang setuju dan setuju. Hal ini sesuai dengan pegawai yang sudah mengerjakan dan mengerti dengan tugas yang dibebankan tanpa perlu adanya tekanan dari pimpinan, namun masih juga ada beberapa pegawai yang tidak diberdayakan secara maksimal untuk berinisiatif dalam melakukan pekerjaan, sehingga pegawai yang berpotensi tidak merata.

\section{h. Kemampuan Supervisi dan Teknik}

Berdasarkan hasil observasi dari pegawai yang menggunakan aplikasi E-absensi terdapat 41 responden dengan presentase 59,4\% yang memberi tanggapan setuju. Hal ini sesuai bahwa setiap pegawai sudah menjalankan tugas sesuai dengan bidangnya dan pegawai memiliki kemampuan untuk mengembangkan pekerjaannya dalam mencapai suatu tujuan.

\section{KESIMPULAN}

Penelitian ini meneliti tentang Pengaruh Implementasi Kebijakan Absen Elektronik (EAbsensi BNI Innivation) Terhadap Kinerja Pegawai Divisi Jakarta Collection Management Pada PT. Bank Negara Indonesia 1946 (persero) Tbk, Jakarta Barat. Berdasarkan hasil penelitian dan pembahasan, maka dapat diambil kesimpulan sebagai berikut : 
1. Implementasi Kebijakan Pada PT. Bank Negara Indonesia 1946 (persero) Tbk, Jakarta Barat sebesar 76,2\% dari kriteria yang ditetapkan.

2. Kinerja Pegawai Kebijakan Pada PT. Bank Negara Indonesia 1946 (persero) Tbk, Jakarta Barat sebesar 73,5\% dari kriteria yang ditetapkan.

3. Pengaruh Implementasi Kebijakan terhadap Kinerja Pegawai sebesar 39,8\% dan 60,2\% dipengaruhi oleh faktor-faktor lain.

\section{SARAN}

Dari beberapa kesimpulan yang telah peneliti kemukakan diatas, selanjutnya peneliti kemukakan saran yang diharapkan dapat bermanfaat sebagai bahan masukan berkaitan dengan Implementasi Kebijakan Absen Elektronik (E-Absensi BNI Innivation) Terhadap Kinerja Pegawai Divisi Jakarta Collection Management Pada PT. Bank Negara Indonesia 1946 (persero) Tbk, Jakarta Barat yaitu :

1. Terindikasi dalam penerapan absensi yaitu kurangnya loyalitas kerja untuk datang lebih awal ke kantor karena dalam absensi bisa melakukan cek-in absen di sekitar kantor cabang lain. Hal ini sesuai dengan indikator pada variable $\mathrm{Y}$ yaitu tentang kehadiran dan ketepatan waktu sehingga hal ini akan berdampak pada kualitas dan kuantitas kerja pegawai, dengan kata lain pegawai harus disosialisasikan serta menghimbau untuk datang tepat waktu. Karena hal ini bertujuan untuk menciptakan kualitas dan kuantitas kerja pegawai yang di harapkan untuk pencapaian perusahaan yang lebih baik.

2. Adanya keluhan pegawai yang sering mengalami gangguan sinyal untuk melakukan cek-in absensi, sehingga mempengaruhi dalam melaksanakan pekerjaan. Hal ini sesuai pada variabel x yaitu ukuran dan tujuan kebijakan yang di lakukan apabila terjadi gangguan sinyal sehingga mengganggu aktivitas pegawai dalam melakukan absen. Maka sejauh mana tolak ukur perusahaan dan kebijakan dalam menanggulangi permasalahan pegawai, sehingga perusahaan harus membuat opsi seperti pencatatan manual absensi atau kebijakan lainnya yang tidak merugikan pegawai.

3. Adanya pegawai yang belum menggunakan absensi elektronik secara menyeluruh sehingga terindikasi kesenjangan lingkungan ekonomi, social, dan politik yang terdapat pada variabel X. hal ini sangatlah berpengaruh terhadap kinerja para pegawai karena dalam ketepatan waktu e-absensi elektronik lebih fleksibel dibanding absen 
lainnya. Harusnya mendata kembali seluruh pegawai yang belum memakai e-absensi elektronik tanpa memandang status

4. pegawai kontrak atau lainnya sehingga pegawai dapat bekerja dengan baik dan mampu menciptakan sumber daya yang berkualitas.

5. Pegawai merasa sering terjadi hambatan untuk validasi absensi dengan sistem, sehingga berdampak pada kehadiran dan ketepatan waktu. Maka di perlukan kemampuan supervisi dan teknik untuk mengatasi hal tersebut. Hal ini sesuai pada variabel $Y$, dengan adanya hambatan tersebut mampu teratasi. 


\section{DAFTAR PUSTAKA}

Agustino, Leo. 2017. Dasar-dasar Kebijakan Publik. Bandung: Alfabeta

Anggara, Sahya. 2018. Kebijakan Publik. Bandung: CV. Pustaka Setia

Arikunto, Cipta Suharsimi. 2013. Prosedur Penelitian. Jakarta: Rineka

Hasibuan, Malayu. 2011. Manajemen dasar, Pengertian dan Masalah. Jakarta: PT. Bumi Aksara

Hasibuan, Malayu. 2014. Organisasi dan Motivasi. Jakarta: PT. Bumi Aksara

Pasolong, Harbani. 2012. Metode Penelitian Administrasi Publik. Bandung: Alfabeta

Priansa, Donni Juni. 2017. Manajemen Kinerja Pegawai. Bandung: CV. Pustaka Setia

Priyatno, Duwi. 2017. Panduan Praktis Oleh Data Menggunakan SPSS. Yogyakarta: Andi

Sugiyono. 2016. Metode Penelitian. Bandung: Alfabeta

Syafri, Wirman. 2012. Studi Tentang Administrasi Publik. Bandung: PT. Gelora Aksara

Pratama

Wahab, Solichin Ahmad. 2017. Analisis Kebijakan. Jakarta: PT. Bumi Aksara

Wibawa Samodra. 2011. Politik Perumusan Kebijakan Publik. Jakarta: Graha Ilmu

Wibowo. 2007. Edisi Kelima Manajemen Kinerja. Depok: PT. Rajagrafindo Persada

\section{Jurnal-Jurnal :}

Fitria, Rona. 2012. “Proses Pembelajaran Dalam Setting Inklusi di Sekolah Dasar”. Jurnal Ilmiah Pendidikan Khusus. Vol. 1, No. 1: 93

Jamil, Muhammad. 2016. “Rotasi Pekerjaan dan Kinerja Karyawan: Peran Kepuasan dan Variasi Keterampilan Kerja Sebagai Variabel Intervening". Jurnal Ekonomi Manajemen dan Sekretari. Vol. 1, No. 2: 96-117

Prihatinta, Triana, dan Wiwoho Rino Desanto. 2017. “Hubungan Tingkat Kehadiran Melalui Penerapan Absensi Finger Print Terhadap Tingkat Disiplin Kerja Karyawan Kontrak di Politeknik Negeri Madiun” Jurnal Epi cheirisi. Vol. 1, No. 1: 8-12

Rukman, Pala. 2013 "Studi Kesiapan Pemerintah Kabupaten Maros dalam Pengimplementasian Sistem Informasi Kehadiran Pegawai Berbasis Elektronik". Jurnal Pekommas. Vol. 16, No. 3: 169-176

Dokumen-Dokumen :

Al-Qur'an, surah Al-A'raaf ayat 39

Website :

http:/ / definisipengertian.net/pengertian-populasi-definisi-sample-teknik-sampling/ https:/ /id.m.wikipedia.org/wiki/Administrasi 
http://www.materibelajar.id/2016/03/implementasi-kebijakan-publikdefinisi.html?m=1\# 